\title{
Islet Cell Cytoplasmic IgG Antibody Measurement
}

National Cancer Institute

\section{Source}

National Cancer Institute. Islet Cell Cytoplasmic Ig G Antibody Measurement. NCI

Thesaurus. Code C122126.

The determination of the amount of islet cell cytoplasmic IgG antibody present in a sample. 